\title{
ПРО ПІДХОДИ ДО РОЗРОБКИ СУЧАСНИХ ПРОГРАМНИХ ДОДАТКІВ В МЕДИЧНІЙ ОСВІТІ
}

\author{
А. В. Семенець, В. П. Марценюк \\ ДВНЗ "Тернопільський державний медичний університет імені І.Я.Горбачевського \\ МОЗ України"

\begin{abstract}
Інформатизація галузі охорони здоров'я та медичної освіти вимагає, серед іншого, розробки спеціалізованих програмних додатків. Визначено концептуальні підходи до розробки та впровадження сучасних програмних додатків в галузі медичної освіти. Показано досвід розробки сучасних програмних додатків в Тернопільському державному медичному університеті імені І. Я. Горбачевського. Проаналізовано підходи до розробки програмних додатків, що використовуються в ТДМУ. Подано рекомендації щодо організації процесу розробки програмного
\end{abstract} \\ забезпечення у закладах медичної освіти.
}

Ключові слова: медична освіта, програмне забезпечення,розробка програмного забезпечення, мова програмування, фреймворк, СУРБД, система контролю версій, віртуалізація.

\section{О ПОДХОДАХ К РАЗРАБОТКЕ СОВРЕМЕННЫХ ПРИЛОЖЕНИЙ В МЕДИЦИНСКОМ ОБРАЗОВАНИИ}

\author{
А. В. Семенец, В. П. Марценюк \\ ГВУз "Тернопольский государственный медицинский университет имени И. Я. Горба- \\ чевского МОЗ Украины"
}

\begin{abstract}
Информатизация здравоохранения и медицинского образования требует, среди прочего, разработки специализированных программных приложений. Определены концептуальные подходы к разработке и внедрению современных программных приложений в области медицинского образования. Показан опыт разработки современных приложений в Тернопольском государственном медицинском университете имени И. Я. Горбачевского. Проанализированы подходы к разработке программных приложений, используемых в ТГМУ. Даны рекомендации по организации процесса разработки программного обеспечения в учреждениях медицинского образования.
\end{abstract}

Ключевые слова: медицинское образование, программное обеспечение, разработка программного обеспечения, язык программирования, фреймворк, СУРБД, система контроля версий, виртуализация.

\section{ON APPROACHES ON THE SOFTWARE DEVELOPMENT FOR THE MEDICAL EDUCATION AREA}

\author{
SHEI "Ternopil State Medical University by I. Ya. Horbachevsky of MPH of Ukraine"
}

\begin{abstract}
Requirements of the development of the special application software for the medical education informatization are shown. The conceptual approaches of the application software development and implementation to the medical e ducation area are determined. The experience of the software development in Ternopil State MedicalUniversity by I. Ya. Horbachevsky is shown. The approaches applied in the software development process in the TSMU are analyzed. The recommendations to the software development process organization in the medical university are offered.
\end{abstract}

Key words: medical education, software, software development, programming language, framework, RDBMS, version control system virtualization.

Вступ. Інформатизація системи охорони здоров'я України належить до числа ключових загальнодержавних завдань. Галузь медичної освіти повинна забезпечити підготовку фахівців, здатних ефективно ви- користовувати можливості сучасних медичних інформаційних систем (MIC), брати участь у їх розробці та супроводженні. Особливого значення набуває розробка та впровадження МIC, які допомагають авто-

() А. В. Семенець, В. П. Марценюк 
матизувати всі аспекти діяльності лікувальної установи $[1,2]$.

Для прикладу, витрати на інформатизацію системи охорони здоров'я в Європейських країнах складають до 5 \% бюджету. Значна частка інвестицій іде на побудову та розвиток МIC. Зокрема, в 2010 р. обсяг фінансування галузі медичної інформатики становив $€ 11$ млрд. Тим не менше, при впровадженні МІС основними проблемами називають складність у стандартизації медичної документації i, увага, - людський чинник - спротив та пасивне ставлення медичних працівників. Останній фактор вказує на важливість впровадження сучасних інформаційнокомунікаційних технологій у галузі медичної освіти як запоруку підготовки фахівців, що готові до використання новинок ПЗ МІС в повсякденній практиці [3].

I. Концептуальні підходи до розробки та впровадження сучасних програмних додатків в галузі медичної освіти України

В роботах $[1,4]$ Семенцем А. В. розглянуто концептуальні напрямки впровадження сучасних інформаційних технологій у галузі медичної освіти, які, зокрема, включають:

- Впровадження інформаційних систем керування навчання (LMS - Learning management system), які часто поєднані з системами дистанційної освіти (СДО), та систем керування навчальними матеріалами (LCMS learning content management system). Стан та перспективи даного напрямку розглядаються в роботах $[5,6]$. Окрім широкого впровадження закордонного ПЗ СКН/СДО/СКНМ є ряд розробок вітчизняного виробництва. Однак нерідко проекти з впровадження ПЗ СКН/СДО/СКНМ здійснюються з численними прорахунками і помилками.

- Формування моделі електронного документообігу. Даний напрям інформатизації галузі медичної освіти України на сьогодні є розвиненим недостатньо. Це є негативним фактором, оскільки можливість централізованого доступу до адміністративних документів та контролю за їх виконанням зазвичай суттєво підвищує якість та ефективність управлінських рішень. Для вирішення задачі формування моделі електронного документообігу існує цілий ряд якісного ПЗ, як комерційного плану, так і з відкритим кодом. Процес автоматизації діловодства в наукових та освітніх організаціях (в тому числі і в закладах медичної освіти) розглядається в роботах $[7,8]$.

- Автоматизація фінансового, кадрового та економічного обліку. Відмінності у принципах ве- дення фінансового, кадрового та економічного обліку у закладах галузі охорони здоров'я, включно 3 медичною освітою, та у сфері бізнесу є невеликими. Це має наслідком використання типових рішень щодо інформатизації фінансово-господарської діяльності закладу медичної освіти.

Наведений вище порядок класифікації відображає точку зору автора на актуальність відповідного концептуального напрямку автоматизації та їх вплив на підвищення якості медичної освіти.

Довільний проект автоматизації освітніх процесів у медичному (фармацевтичному) навчальному закладі можна реалізувати в рамках наступних трьох альтернативних підходів:

1. Впровадження існуючого комерційного ПЗСКН/СДО/СКНМ. В освітній галузі України застосовується цілий ряд комерційних продуктів, як вітчизняних, так і закордонних (насамперед російських) розробників [9]. Основним стримуючим фактором для поширення комерційного ПЗ $є$ висока вартість та закритість програмного коду.

2. Адаптація вільно-розповсюджуваного ПЗ СКН/СДО/СКНМ з відкритим кодом. 3 точки зору автора, це найбільш раціональний і виправданий крок. Зокрема, на сайті спільноти Moodle (http:// moodle.org/) офіційно зареєстровано більше 100 українських навчальних закладів, що використовують СДО Moodle [9]. Процес адаптації такого ПЗ відповідно до потреб окремого закладу медичної освіти розглянуто Семенцем А. В. у роботах [10 - 13].

3. Розробка власного, спеціально спроектованого ПЗСКН/СДО/СКНМ. Представлення досвіду розробки ПЗ для галузі медичної освіти в ТДМУ $\epsilon$ основною метою роботи та буде детально розглянуто далі.

II. Розробка спеціально спроектованого ПЗ для потреб галузі медичної освіти в ТДМУ

Основні фактори, що мають суттєвий вплив на процес і результат автоматизації інформаційних процесів у медичному навчальному закладі, та $є$ спільними для всіх перелічених альтернативних підходів (див.п. 1), включають:

1. Організаційний фактор - правильне визначення цілей і задач проекту розробки чи/та впровадження СКН/СДО/СКНМ.

2. Бюджетний фактор - наявність фінансового забезпечення проекту розробки чи/та впровадження СКН/СДО/СКНМ.

3. Людський фактор - наявність людських ресурсів та їх готовність до проекту розробки чи/та впровадження СКН/СДО/СКНМ. 
Протягом останнього десятиліття в навчальний процес ТДМУ запроваджено ряд нових методик та підходів до підготовки майбутніх спеціалістів, більша частина яких грунтується на використанні цілого ряду сучасних інформаційних технологій, ресурсів та систем $[14,15]$. При цьому періодично виникала потре- ба у вирішенні окремих задач інформатизації шляхом розробки нових програмних додатків. На сьогоднішній день в ТДМУ розроблено, підтримується та перебуває в експлуатації ряд ПЗ, що включає як окремі програмні додатки, так і цілі програмні комплекси (див. табл. 1).

Таблиця 1. Перелік ПЗ, розробленого в ТДМУ за останні 10 років

\begin{tabular}{|c|c|c|c|c|c|c|c|}
\hline $\begin{array}{l}\text { № } \\
\text { 3a/ } \\
\text { П }\end{array}$ & $\begin{array}{c}\text { Назва ПЗ, } \\
\text { рік розробки, сайт }\end{array}$ & Автори & $\begin{array}{c}\text { Тип } \\
\text { додатку, } \\
\text { платформа }\end{array}$ & $\begin{array}{c}\text { Мова і засоби } \\
\text { розробки }\end{array}$ & $\begin{array}{c}\text { № a/c, } \\
\text { публікації }\end{array}$ & $\begin{array}{l}\text { Програм- } \\
\text { ний код } \\
\text { (GitHub) }\end{array}$ & Поточний статус \\
\hline 1 & 2 & 3 & 4 & 5 & 6 & 7 & 8 \\
\hline 1 & $\begin{array}{l}\text { "Генератор } \\
\text { Білетів", } \\
(2 \text { версії) } \\
2005 \text { - } 2007\end{array}$ & Семенець А. В. & $\begin{array}{l}\text { Настільний } \\
\text { додаток. } \\
\text { OC Windows }\end{array}$ & \begin{tabular}{|} 
Object Pascal \\
(Delphi). \\
Фреймворк: \\
Ehlib, FIBPlus. \\
СУРБД: \\
Firebird \\
\end{tabular} & & & $\begin{array}{l}\text { Практично } \\
\text { використовується } \\
\text { при підготовці } \\
\text { іспитів } \\
\text { ОСКІ/ОСПІ }\end{array}$ \\
\hline 2 & $\begin{array}{l}\text { "Програмне середо- } \\
\text { вище фармакокіне- } \\
\text { тичних системних } \\
\text { досліджень", } 2009\end{array}$ & $\begin{array}{l}\text { Марценюк В. П. } \\
\text { Андрущак I. Є. }\end{array}$ & \begin{tabular}{|c|} 
Настільний \\
додаток. \\
Крос-плат- \\
формовий
\end{tabular} & $\begin{array}{c}\text { Java. } \\
\text { Фреймворк: } \\
\text { Swing. } \\
\text { СУРБД: } \\
\text { MySQL }\end{array}$ & [16] & & $\begin{array}{l}\text { Засіб проведення } \\
\text { наукових } \\
\text { досліджень в } \\
\text { ТДМУ }\end{array}$ \\
\hline 3 & $\begin{array}{l}\text { "Інформаційна } \\
\text { система рейтин- } \\
\text { гового оцінювання } \\
\text { діяльності викла- } \\
\text { дачів ВМ(Ф)НЗ } \\
\text { України", } 2009\end{array}$ & $\begin{array}{l}\text { Марценюк В. П. } \\
\text { Стаханська О. О. }\end{array}$ & \begin{tabular}{|c} 
Веб- \\
додаток. \\
Крос- \\
платформо- \\
вий
\end{tabular} & \begin{tabular}{|c|} 
Jаva. \\
Фреймворки: \\
JSP, SweetDev- \\
RIA. \\
СУРБД: \\
MySQL \\
\end{tabular} & [17] & & $\begin{array}{l}\text { Практично вико- } \\
\text { ристовується для } \\
\text { рейтингового оці- } \\
\text { нювання роботи } \\
\text { викладачів } \\
\text { університету } \\
\end{array}$ \\
\hline 4 & $\begin{array}{l}\text { "Інформаційна } \\
\text { система перевірки } \\
\text { знань в медичній } \\
\text { освіті (ІСПЗМО)", } \\
\text { (2 версіі), } \\
\text { 2008-2010. }\end{array}$ & $\begin{array}{l}\text { Семенець А. В., } \\
\text { Марценюк В. П. }\end{array}$ & \begin{tabular}{|c|} 
Клієнт- \\
серверний \\
додаток, \\
OC Windows
\end{tabular} & $\begin{array}{l}\text { Object Pascal } \\
\text { (Delphi). } \\
\text { Фреймворки: } \\
\text { Ehlib, FIBPlus, } \\
\text { FastReport. } \\
\text { СУРБД: } \\
\text { Firebird }\end{array}$ & $\begin{array}{c}\text { А/с на } \\
\text { службовий } \\
\text { твір } \\
\text { № } 32268 \\
\text { від } \\
1.03 .2010 \\
{[18]}\end{array}$ & $\begin{array}{l}\text { https://gith } \\
\text { ub.com/se } \\
\text { mteacher/T } \\
\text { estMarer3 }\end{array}$ & $\begin{array}{l}\text { Практично } \\
\text { використовується } \\
\text { при підготовці } \\
\text { семестрового } \\
\text { тестового іспиту }\end{array}$ \\
\hline 5 & $\begin{array}{l}\text { "Автоматизована } \\
\text { система для опра- } \\
\text { цювання резуль- } \\
\text { татів оцінювання } \\
\text { студентів та збору } \\
\text { статистики", } 2009 .\end{array}$ & Чеканов С. Б. & $\begin{array}{c}\text { Клієнт- } \\
\text { серверний } \\
\text { додаток, } \\
\text { OC Windows }\end{array}$ & $\begin{array}{l}\text { C++ (Visual } \\
\text { Studio). } \\
\text { Фреймворк: } \\
\text { FIBPlus. } \\
\text { СУРБД: } \\
\text { MySQL } \\
\end{array}$ & & & $\begin{array}{l}\text { Практично } \\
\text { використовується } \\
\text { при обробці } \\
\text { результатів } \\
\text { семестрового } \\
\text { тестового іспиту } \\
\end{array}$ \\
\hline 6 & $\begin{array}{l}\text { Інформаційна } \\
\text { система лаборатор- } \\
\text { ної діагностики на } \\
\text { основі поляризацій- } \\
\text { ної флуоресценції } \\
\text { жовчі, } 2010 .\end{array}$ & $\begin{array}{l}\text { Ковальчук О. Л. } \\
\text { Марценюк В. П. }\end{array}$ & \begin{tabular}{|} 
Настільний \\
додаток. \\
Крос- \\
платформо- \\
вий
\end{tabular} & $\begin{array}{c}\text { Java. } \\
\text { Фреймворк: } \\
\text { Swing. } \\
\text { СУРБД: } \\
\text { MySQL. }\end{array}$ & [19] & & $\begin{array}{l}\text { Засіб проведення } \\
\text { наукових } \\
\text { досліджень в } \\
\text { ТдМУ }\end{array}$ \\
\hline 7 & $\begin{array}{l}\text { "Відвідуваність } \\
\text { навчально- } \\
\text { практичних центрів } \\
\text { первинної медико- } \\
\text { санітарної } \\
\text { допомоги ТдМУ", } \\
2012 . \\
\text { (http://test.tdmu.edu.ua } \\
\text { /JMedRegServerZK/) }\end{array}$ & Семенець А. В. & \begin{tabular}{|c} 
Інтеграція \\
клієнт- \\
серверного \\
та веб \\
додатків. \\
Крос- \\
платформо- \\
вий
\end{tabular} & $\begin{array}{c}\text { Java } \\
\text { (Nenbeans). } \\
\text { Фреймворки: } \\
\text { Swing, AWT, } \\
\text { ZK. } \\
\text { СУРБД: } \\
\text { MySQL, } \\
\text { HSQL. }\end{array}$ & & $\begin{array}{l}\text { https:/gith } \\
\text { ub.com/se } \\
\text { mteacher/J } \\
\text { MedRegSe } \\
\text { rverZK }\end{array}$ & $\begin{array}{l}\text { Практично } \\
\text { використовується } \\
\text { при аналізі } \\
\text { ефективності } \\
\text { роботи вказаних } \\
\text { центів }\end{array}$ \\
\hline
\end{tabular}


Продовження табл. 1

\begin{tabular}{|c|c|c|c|c|c|c|c|}
\hline 1 & 2 & 3 & 4 & 5 & 6 & 7 & 8 \\
\hline 8 & $\begin{array}{l}\text { Система самозапису } \\
\text { пацієнтів до лікарів } \\
\text { університетської } \\
\text { лікарні, 2012. } \\
\text { http://medicine.te.ua/ } \\
\end{array}$ & $\begin{array}{c}\text { Чеканов С. Б. } \\
\text { Семенець А. В. } \\
\text { Марценюк В. П. }\end{array}$ & $\begin{array}{c}\text { Веб- } \\
\text { додаток. } \\
\text { Крос- } \\
\text { платфор- } \\
\text { мовий }\end{array}$ & $\begin{array}{c}\text { РНР, } \\
\text { JavaScript. } \\
\text { Фреймворк } \\
\text { JQuery. } \\
\text { СУРБД: } \\
\text { MySQL } \\
\end{array}$ & [20] & $\begin{array}{l}\text { https://gith } \\
\text { ub.com/MI } \\
\text { LLKA3000 } \\
\text { medicine.te } \\
\text {.ua }\end{array}$ & $\begin{array}{l}\text { Практично ви- } \\
\text { користовується } \\
\text { для самозапису } \\
\text { пацієнтів до лі- } \\
\text { карів універси- } \\
\text { тетської лікарні }\end{array}$ \\
\hline 9 & $\begin{array}{l}\text { Система самозапису } \\
\text { пацієнтів до лікарів } \\
\text { університетської } \\
\text { лікарні, } 2012 .\end{array}$ & $\begin{array}{l}\text { Семенець А. В., } \\
\text { Марценюк В. П. }\end{array}$ & $\begin{array}{c}\text { Веб- } \\
\text { додаток. } \\
\text { Крос- } \\
\text { платфор- } \\
\text { мовий }\end{array}$ & $\begin{array}{c}\text { Java } \\
\text { (Nenbeans). } \\
\text { Фреймворк: } \\
\text { JSP. } \\
\text { СУРБД: } \\
\text { MySQL } \\
\end{array}$ & & $\begin{array}{l}\text { https://gith } \\
\text { ub.com/se } \\
\text { mteacher/J } \\
\text { medicallnf } \\
\text { ormation } \\
\text { System } \\
\end{array}$ & $\begin{array}{l}\text { Тестове } \\
\text { середовище }\end{array}$ \\
\hline 10 & $\begin{array}{l}\text { Інформаційна система } \\
\text { "Рейтингове } \\
\text { оцінювання студентів } \\
\text { М(Ф)ВНЗ", } 2013 .\end{array}$ & Чеканов С. Б. & $\begin{array}{c}\text { Веб- } \\
\text { додаток. } \\
\text { Крос- } \\
\text { платфор- } \\
\text { мовий }\end{array}$ & $\begin{array}{c}\text { РНР, } \\
\text { JavaScript. } \\
\text { Фреймворки } \\
\text { CakePHР, } \\
\text { JQuery. } \\
\text { СУРБД: } \\
\text { MySQL }\end{array}$ & & & $\begin{array}{l}\text { Практично } \\
\text { використову- } \\
\text { ється для } \\
\text { рейтингового } \\
\text { оцінювання } \\
\text { студентів } \\
\text { ТДМУ }\end{array}$ \\
\hline 11 & $\begin{array}{l}\text { "Визначення якості } \\
\text { оцінювання знань та } \\
\text { практичної ком- } \\
\text { петентності в ін- } \\
\text { формаційній системі } \\
\text { управління якістю } \\
\text { підготовки фахівців- } \\
\text { медиків", 2013. }\end{array}$ & $\begin{array}{c}\text { Марценюк В. П. } \\
\text { Сельський П. Р. } \\
\text { Чеканов С.Б. }\end{array}$ & $\begin{array}{c}\text { Веб- } \\
\text { додаток. } \\
\text { Крос- } \\
\text { платфор- } \\
\text { мовий }\end{array}$ & $\begin{array}{c}\text { РНР, } \\
\text { JavaScript. } \\
\text { Фреймворк } \\
\text { JQuery. } \\
\text { СУРБД: } \\
\text { MySQL }\end{array}$ & $\begin{array}{c}\text { А/с на } \\
\text { службовий } \\
\text { твір } \\
\text { № } 53202 \\
\text { від } 20.01 . \\
2014\end{array}$ & $\begin{array}{l}\text { https://gith } \\
\text { ub.com/MI } \\
\text { LLKA3000 } \\
/ \\
\text { validnist }\end{array}$ & $\begin{array}{l}\text { Практично } \\
\text { використову- } \\
\text { ється при ана- } \\
\text { лізі результатів } \\
\text { семестрового } \\
\text { тестового } \\
\text { іспиту }\end{array}$ \\
\hline 12 & \begin{tabular}{|l} 
"Програмне сере- \\
довище визначення \\
параметрів медичного \\
страхового полісу \\
відповідно до \\
етіології \\
захворювання, 2013. \\
\end{tabular} & $\begin{array}{c}\text { Марценюк В. П. } \\
\text { Климук Н. Я. }\end{array}$ & \begin{tabular}{|c|} 
Настільний \\
додаток. \\
Крос- \\
платфор- \\
мовий
\end{tabular} & $\begin{array}{c}\text { Java. } \\
\text { Фреймворк: } \\
\text { Swing. } \\
\text { СУРБД: } \\
\text { MySQL }\end{array}$ & $\begin{array}{c}\text { А/с на } \\
\text { службовий } \\
\text { твір } \\
\text { № } 50842 \\
\text { від } 21.08 . \\
2013\end{array}$ & & $\begin{array}{l}\text { Засіб } \\
\text { проведення } \\
\text { наукових } \\
\text { досліджень в } \\
\text { ТДМУ }\end{array}$ \\
\hline 13 & $\begin{array}{l}\text { "Інформаційна } \\
\text { система підтримки } \\
\text { прийняття рішення } \\
\text { "Вагітність", } 2013 .\end{array}$ & $\begin{array}{c}\text { Семенець А. В., } \\
\text { Жиляєв М. М., } \\
\text { Геряк С. М. }\end{array}$ & \begin{tabular}{|c|} 
Настільний \\
додаток. \\
OC Win- \\
dows
\end{tabular} & $\begin{array}{c}\text { VВА. } \\
\text { СУРБД: } \\
\text { MS Access }\end{array}$ & $\begin{array}{c}\text { А/с на } \\
\text { службовий } \\
\text { твір № } \\
51256 \text { від } \\
16 . \\
09.2013 \\
\end{array}$ & & $\begin{array}{l}\text { Засіб } \\
\text { проведення } \\
\text { наукових } \\
\text { досліджень в } \\
\text { ТдМУ }\end{array}$ \\
\hline 14 & $\begin{array}{l}\text { "Інформаційна } \\
\text { система лабораторної } \\
\text { діагностики } \\
\text { політравм", } 2013 .\end{array}$ & $\begin{array}{c}\text { Борис Р. М., } \\
\text { Марценюк В. П. }\end{array}$ & \begin{tabular}{|c|} 
Настільний \\
додаток. \\
Крос- \\
платформо \\
вий \\
\end{tabular} & $\begin{array}{c}\text { Java. } \\
\text { Фреймворк: } \\
\text { Swing. } \\
\text { СУРБД: } \\
\text { MySQL }\end{array}$ & [21] & & $\begin{array}{l}\text { Засіб } \\
\text { проведення } \\
\text { наукових } \\
\text { досліджень в } \\
\text { ТдМУ } \\
\end{array}$ \\
\hline 15 & $\begin{array}{l}\text { "Програмне } \\
\text { середовище } \\
\text { епідеміологічних } \\
\text { системних } \\
\text { досліджень", } 2014 .\end{array}$ & $\begin{array}{l}\text { Марценюк В. П. } \\
\text { Кучвара О. М. }\end{array}$ & \begin{tabular}{|c|} 
Настільний \\
додаток. \\
Крос- \\
платфор- \\
мовий \\
\end{tabular} & $\begin{array}{l}\text { Java. } \\
\text { Фреймворк: } \\
\text { Swing. } \\
\text { СУРБД: } \\
\text { MySQL } \\
\end{array}$ & [22] & & $\begin{array}{l}\text { Засіб } \\
\text { проведення } \\
\text { наукових } \\
\text { досліджень в } \\
\text { ТДМУ } \\
\end{array}$ \\
\hline 16 & $\begin{array}{l}\text { Інформаційна система } \\
\text { "Рейтинг викладачів - } \\
2014 ", 2014 .\end{array}$ & Семенець А. В. & $\begin{array}{c}\text { Веб- } \\
\text { додаток. } \\
\text { Крос- } \\
\text { платфор- } \\
\text { мовий }\end{array}$ & $\begin{array}{c}\text { РНР, } \\
\text { JavaScript. } \\
\text { Фреймворки: } \\
\text { YII, JQuery. } \\
\text { СУРБД: } \\
\text { MySQL }\end{array}$ & & $\begin{array}{l}\text { https://gith } \\
\text { ub.com/se } \\
\text { mteacher/tr } \\
\text { atingyii }\end{array}$ & $\begin{array}{l}\text { Тестове } \\
\text { середовище }\end{array}$ \\
\hline
\end{tabular}


Продовження табл. 1

\begin{tabular}{|c|c|c|c|c|c|c|c|}
\hline 1 & 2 & 3 & 4 & 5 & 6 & 7 & 8 \\
\hline 17 & $\begin{array}{l}\text { Інформаційна } \\
\text { система "Рейтинг } \\
\text { викладачів - 2014", } \\
2014 .\end{array}$ & Семенець А. В. & $\begin{array}{c}\text { Веб- } \\
\text { додаток. } \\
\text { Крос- } \\
\text { платфор- } \\
\text { мовий }\end{array}$ & $\begin{array}{l}\text { PHР, JavaScript. } \\
\text { Фреймворки: } \\
\text { ZendFramework } \\
\text {, JQuery. } \\
\text { СУРБД: } \\
\text { MySQL }\end{array}$ & & $\begin{array}{l}\text { https://githu } \\
\text { b.com/semt } \\
\text { eacher/trati } \\
\text { gphp }\end{array}$ & $\begin{array}{l}\text { Тестове } \\
\text { середовище }\end{array}$ \\
\hline 18 & $\begin{array}{l}\text { "Інформаційна } \\
\text { система } \\
\text { психологічного } \\
\text { тестування } \\
\text { студентів та } \\
\text { працівників ВН3", } \\
2014 .\end{array}$ & Чеканов С. Б. & $\begin{array}{c}\text { Веб- } \\
\text { додаток. } \\
\text { Крос- } \\
\text { платфор- } \\
\text { мовий }\end{array}$ & $\begin{array}{l}\text { PHР, JavaScript. } \\
\text { Фреймворки: } \\
\text { СakePHР, } \\
\text { JQuery. } \\
\text { СУРБД: } \\
\text { MySQL }\end{array}$ & & & $\begin{array}{l}\text { Використову- } \\
\text { ється для психо- } \\
\text { логічного } \\
\text { тестування } \\
\text { студентів та } \\
\text { працівників } \\
\text { університету }\end{array}$ \\
\hline
\end{tabular}

III. Аналіз підходів до розробки спеціально спроектованого ПЗ для потреб галузі медичної освіти, що застосовуються в ТДМУ

Авторами було проведено аналіз інформації про розроблене протягом останнього десятиліття в ТДМУ ПЗ (табл. 1). Результати аналізу показують існування певних тенденцій стосовно підходівдо процесу розробки ПЗ в ТДМУ.

Протягом спостережуваного періоду співробітниками ТДМУ реалізовано розробку 20 проектів ПЗ IC різного призначення (рис. 1) та типу (рис. 2, 3). Більша частина ПЗ в ТДМУ розроблена для підтримки навчального процесу (9 проектів). Позитивною рисою $\epsilon$ активізація як процесу розробки ПЗ протягом ос- танніх 5 років в цілому, так і розробки ПЗ для проведення наукових досліджень (6 проектів) зокрема. Слід також зазначити наступне:

1. Під терміном "Тестове середовище" автори мають на увазі повністю робочий програмний додаток, який, проте, не був прийнятий в практичну експлуатацію з певних причин.

2. В даний перелік не включено велику кількість наукових та практичних експериментів в галузі алгоритмізації чи тестування певних технологій і засобів розробки ПЗ, що були здійснені працівниками ТДМУ, оскільки їх результати не передбачали реалізацію повнофункціонального ПЗ.

\section{Розробка ПЗ в ТдМУ - IC за призначенням}

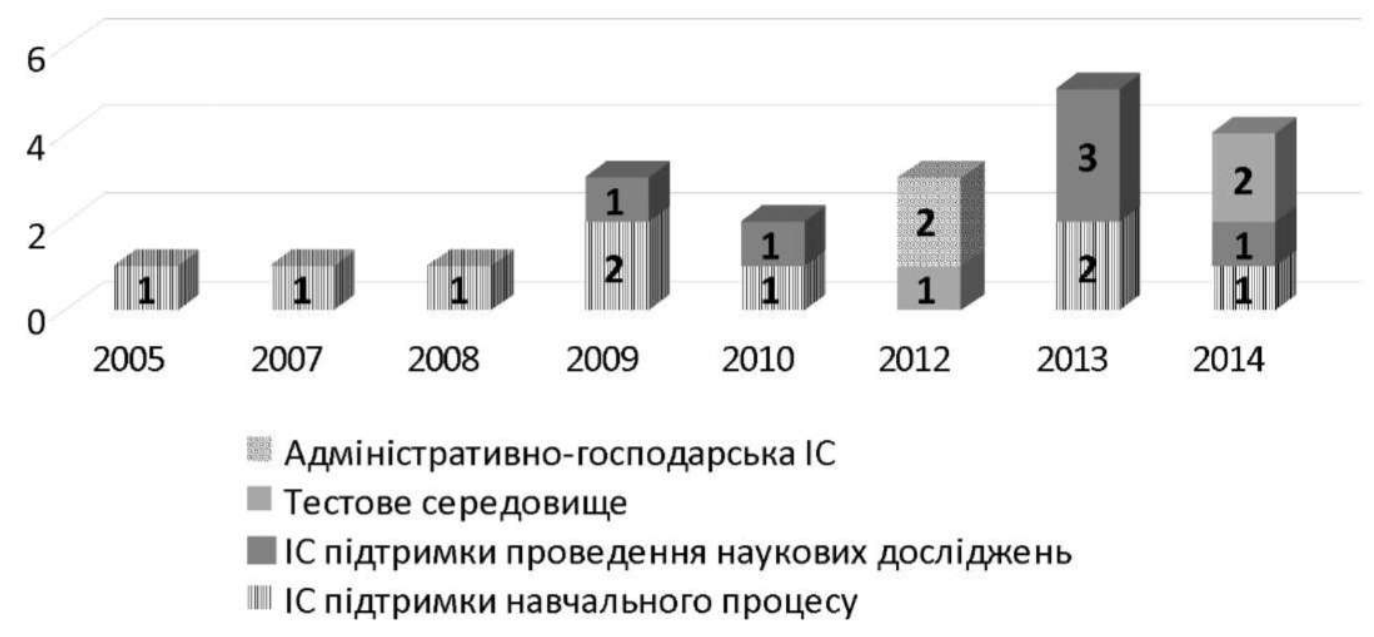

Puc. 1. Номенклатура ПЗ, що розроблялося в ТДМУ, за призначенням.

Суттєво зростає частка веб-додатків у структурі програмних розробок ТДМУ - 9 проектів, 3 яких 8 реалізовані протягом останніх 3 років (рис. 2). Деяке негативне враження має відносно висока частка настільних додатків серед розробленого ПЗ - 7 проектів, 3 них 3 - протягом ос- 
танніх 3 років. Позитивне враження справляє практично повний перехід до розробки крос-платфор- мових додатків -11 проектів 312 протягом тих же останніх 3 років.

Розробка пз в тдму- Пз за типами

6

4

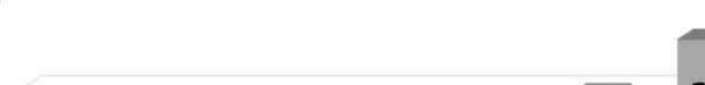

0

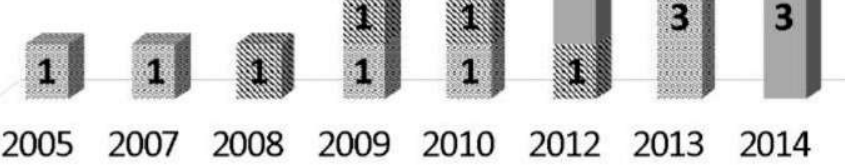

Настільний додаток Клієнт-серверний Веб-додаток

Puc. 2. Номенклатура ПЗ, що розроблялося в ТДМУ, за типом.

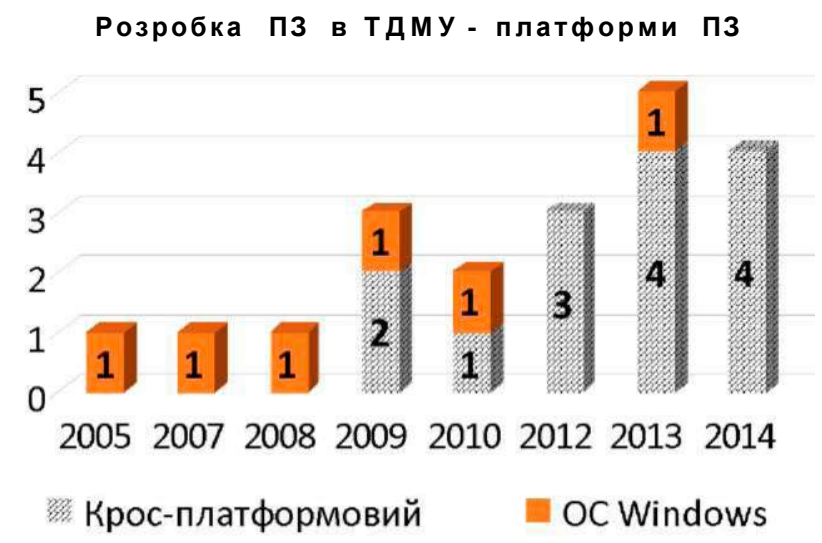

Puc. 3. Номенклатура ПЗ, що розроблялося в ТДМУ, по платформах.

В розрізі засобів розробки ПЗ спостерігається домінування таких мов програмування як Java (8 проектів), РНP та JavaScript - по 6 проектів (рис. 4). При цьому, частка використання пари PHP - JavaScript зростає протягом останніх 3 років (рис. 5) - 6 проектів сумарно. I навпаки, фактично припинено розробку додатків мовою Object Pascal.

\section{Використання мов програмування в ТДМУ}

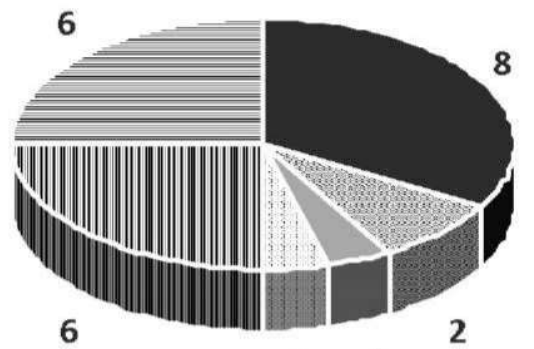

- Java Ubject Pascal = VBA ${ }^{1} \mathrm{C}^{\frac{1}{++}}$ III PHP $=$ JavaScript

Рuc. 4. Основні мови програмування для розробки ПЗ в ТДМУ 


\section{Використання мов програмування в ТДМУ}

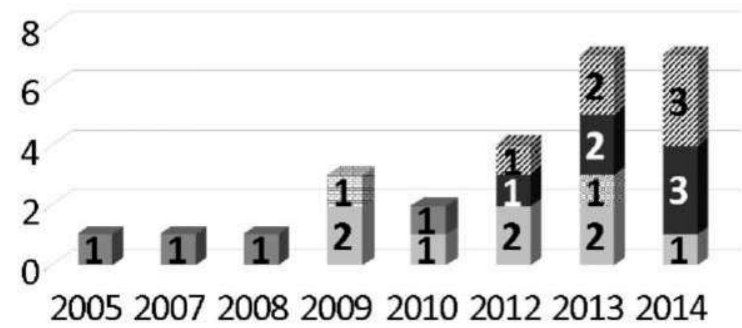

Java $\square$ Object Pascal

Puc. 5. Динаміка змін використання мов програмування для розробки ПЗ в ТДМУ.

Сучасний підхід до розробки ПЗ передбачає обов'язкове використання фреймворків в рамках загальної парадигми швидкої розробки додатків (RAD-Rapid Application Development). Діаграма (рис. 6) відображає кількісний склад фреймворків (без врахування окремих бібліотек та віджетів), що застосовувалися розробниками в ТДМУ. Найчастіше використовувалися такі фреймворки як Swing (Java) i JQuery (JavaScript) - по 6 проектів, та EhLib (Object Pascal / Delpih) - в 4 проектах. В той же час діаграма (рис. 7) показує:
- припинення використання фреймворків для мови програмування Object Pascal (Delpih) після 2010 року; - розширення номенклатури застосовуваних фреймворків в при розробці П3 з 2-3 до 6-7 за останні 3 роки.

Актуальність використання сучасних фреймворків при розробці ПЗ, особливо у випадку розробки вебдодатків, розглянуто в багатьох роботах, наприклад $[23,24]$. Існує велика кількість безкоштовних фреймворків для всіх популярних мов програмування [25].

Використання фреймворків при розробці ПЗ

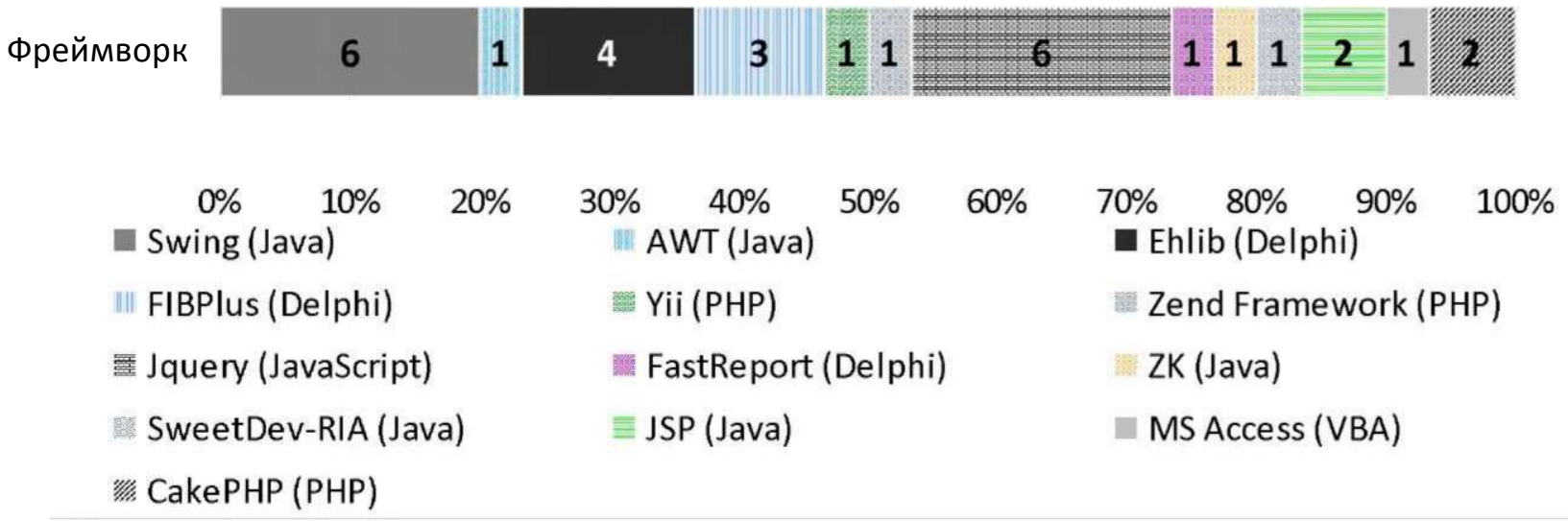

Puc. 6. Основні фреймворки мов програмування для розробки ПЗ в ТДМУ.

Додатковою ілюстрацією фундаментальності вказаного підходу на сучасному етапі розробки ПЗ слугує просте порівняння якості користувацького інтерфейсу наступних веб-додатків (рис. 8, 9):

- " Інформаційна система рейтингового оцінювання діяльності викладачів ВМ(Ф)НЗ України" (3 в табл. 1) - написаний лише з використанням базового фреймворку - бібліотеки JSP. Вказаний в таблиці 1 фреймворк SweetDev-RIA використовується лише для сторінки представлення остаточного рейтингу викладачів ТДМУ.

- "Відвідуваність навчально-практичних центрів первинної медико-санітарної допомоги ТДМУ" - написаний повністю з використанням Јava-фреймворку, призначеного саме для розробки веб-додатків ZK (http ://www.zkoss.org/product/zk). 


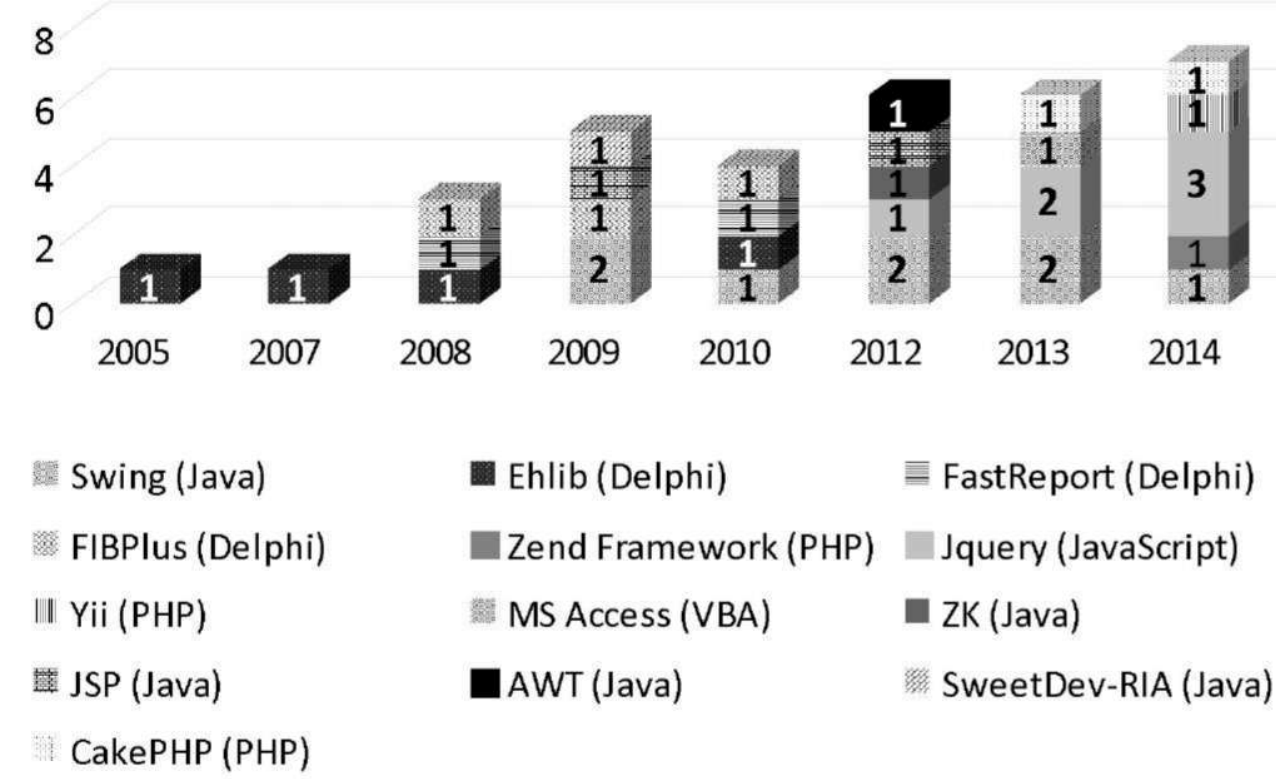

Puc. 7. Динаміка змін використання фреймворків мов програмування для розробки ПЗ в ТДМУ.

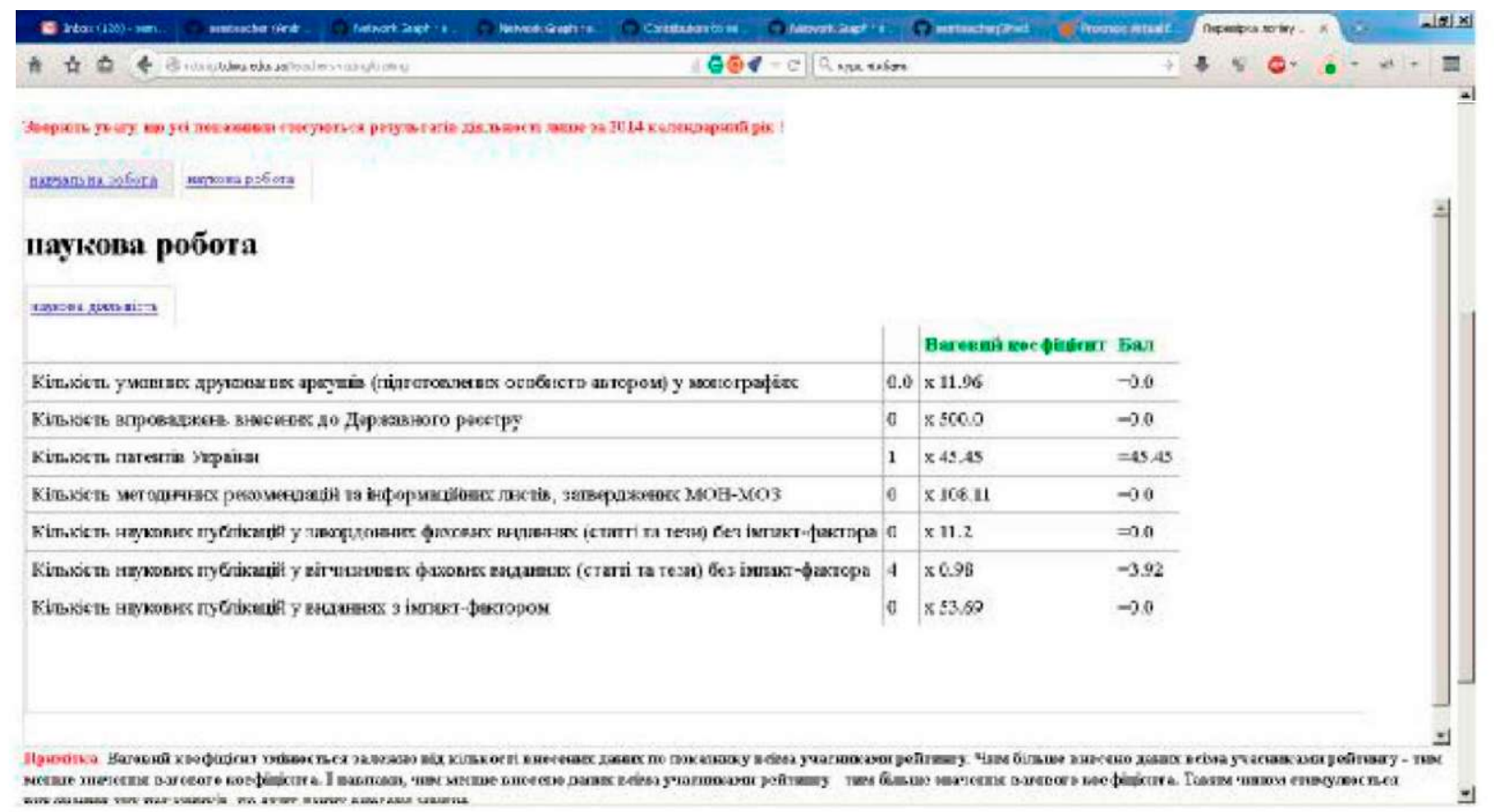

Puc. 8. Інтерфейс веб-додатка на мові Јаva - застосовано лише базовий веб-фреймворк - бібліотеку JSP.

Об'єктивно інтерфейс другого додатка (рис. 9) є більш зручним, інтуїтивно зрозумілим та дружнім по відношенню до користувача.

Одночасно певне занепокоєння викликає доволі широке застосування фреймворку Swing для настільних Јаvа-додатків. Корпорація Oracle, якій за- раз належить право власності на мову Јava, визнала цю технологію застарілою і припинила ії розвиток та підтримку. Сучасною альтернативою для розробки настільних Јаvа-додатків є технологія Java FX [26] та відповідний фреймворк. 


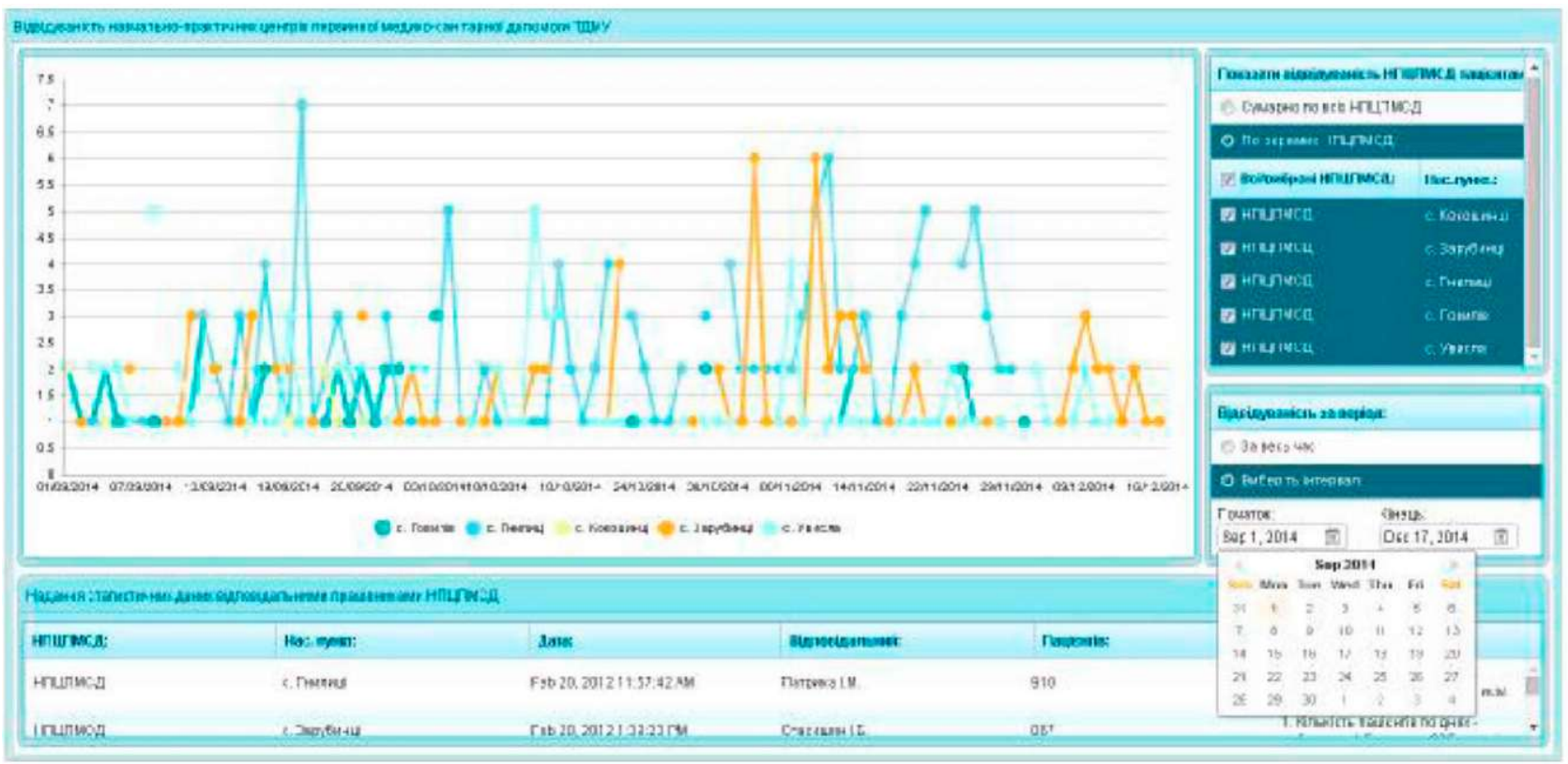

Puc. 9. Інтерфейс веб-додатка на мові Java - застосовано спеціалізований веб-фреймворк ZK.

В розрізі використання певної СУРБД для зберігання даних в ТДМУ спостерігається однозначне домінування СУРБД MySQL (рис. 10), частка ви- користання якої при розробці ПЗ в ТДМУ становить $80 \%$.

\section{Застосування СУРБД при розробці ПЗ}

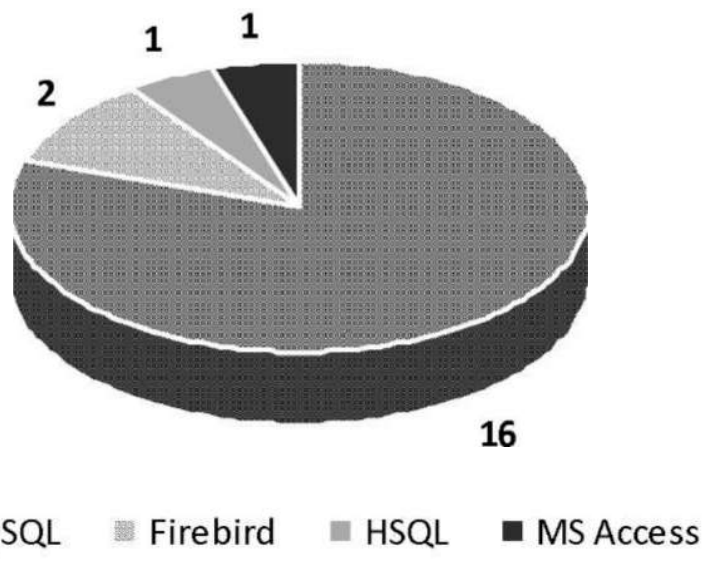

Puc. 10. Основні СУРБД в проектах з розробки ПЗ в ТДМУ.

Автори вважають за необхідне окремо відзначити ряд інших особливостей процесу розробки ПЗ в ТДМУ. Зокрема у 2012 році вперше в практиці програмістів ТДМУ А. В. Семенець для керування процесом модифікації програмного коду модуля застосував систему контролю версій Git (http://git-scm.com/). Зараз система контролю версій Git та сервер GitHub (https:/github.com/) використовуються для підтримки процесу розробки більшості програмних додатків в ТДМУ (рис. 11).
Застосування сучасних систем контрою версій дозволяє:

- контролювати історію внесення змін в програмний код проекту;

- колективну роботу над проектом розробникам, що можуть знаходитися в будь-якій точці світу;

- інформування основного розробника про зміни, які вносять інші учасники проекту;

- взаємний обмін ідеями та програмними рішен нями. 


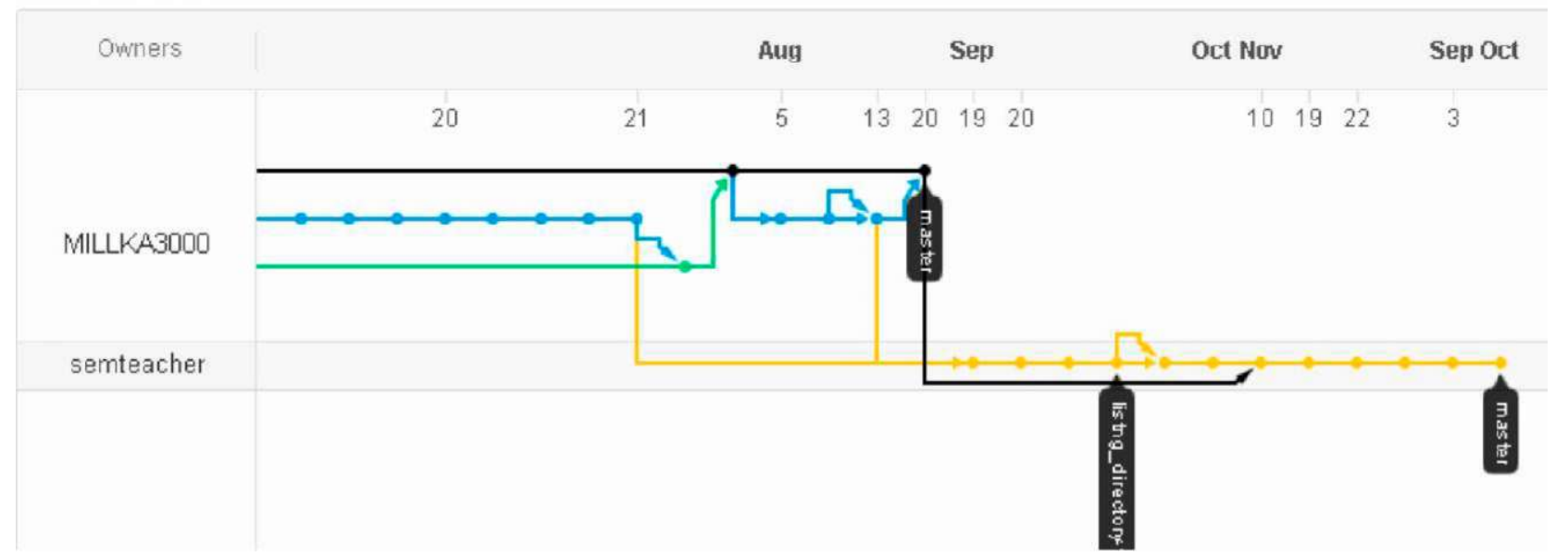

Puc. 11. Візуалізація процесу спільної роботи над програмним додатком з використанням системи контроль версій Git та сервера GitHub.

На початку 2013 року в ТДМУ за ініціативи авторів роботи було створено мережевий кластер високої доступності, як один з етапів реалізації комплексу заходів по реорганізації інформаційної інфраструктури ВНЗ [27]. Проект реалізовано з застосуванням програмного середовища віртуалізації з відкритим кодом Proxmox VE (https://www.proxmox.com/ proxmox-ve). Один 3 позитивних наслідків такого рішення - можливість швидко створювати віртуальні сервери на основі типових налаштувань. Очевидним було рішення здійснювати тестування та відлагодження ПЗ в процесі його розробки на окремих віртуальних серверах.

Ефективним інструментом формування сучасного освітнього середовища, в тому числі і в галузі медичної освіти, є хмарні технології. У 2013 році автором спільно з колегами було прийнято рішення розпочати переведення окремих інформаційних сервісів інтранет-мережі ТДМУ в хмарне середовище Google Apps For Education [28]. Вказаний крок також був одним з етапів реалізації комплексу заходів з реорганізації інформаційної інфраструктури ВНЗ. Таким чином, програмісти ТДМУ отримали можливість застосовувати інструменти Google Apps For Developers в проектах розробки ПЗ:

1. Розпочалося застосування механізму аутен тифікації Oauth2. Першою реалізацією стало використання даного методу аутентифікації для автоматичної авторизації користувачів 3 домену ТДМУ у веб-додатку "Відвідуваність навчально-практичних центрів первинної медико-санітарної допомоги ТДМУ" (7 у табл. 1). Для цього застосовано програмну бібліотеку Google APIs Client Library for Java (http://code. google. com/p/google-api-j ava-client/).
Здійснюється адаптація інших веб-додатків (рис. 12).

Можливості сервісу Google Sites щодо швидкої розробки простих веб-сайтів використано для створення 2 сайтів для внутрішнього користування. Сайт "Адміністраторів та інженерів ТДМУ" (https:// sites. google. com/a/tdmu. edu.ua/admin-site/) містить технічну та адміністративну документацію для розробників, зокрема, перелік та лінки до всіх репозиторіїв на сервері GitHub. Доступ до сайту обмежений і надається лише членам групи розробки ПЗ та системним адміністраторам ТДМУ Іншим прикладом $\epsilon$ сайт "Я навчусь програмувати" (https:// sites.google.com/a/tdmu.edu.ua/i-am-learning/), створений в ініціативному порядку окремими працівниками групи розробки ПЗ для підвищення кваліфікації колег чи навчання програмуванню веб-додатків всіх бажаючих. Сайт знаходиться у відкритому доступі.

Висновки. Впровадження інформаційно-комунікаційних технологій - необхідна умова підвищення якості медичної освіти. Застосування існуючого та розробка власного ПЗ є одним з складових елементів сучасних методів навчання. На основі досвіду розробки ряду програмних продуктів (див. табл. 1) автори зробилинаступні висновки щодо перспектив та підходів до розробки власних додатків у медичному (фармацевтичному) ВН3:

1. Розробка власних програмних додатків є доцільною лише у тому випадку, якщо потрібне унікальне ПЗ, аналогів якого немає або їх використання 3 суттєвих причин $є$ неможливим. Адміністрація закладу повинна усвідомлювати, що процес розробки цілісного і якісного програмного продукту є складним, тривалим і дорогим. 


\title{
- Відвідуваність НПЦПМСД ТДМУ would like to:
}

\section{View your email address}

8 View your basic profile info

\begin{abstract}
By clicking Accept, you allow this app and Google to use your information in accordance with their respective terms of service and privacy policies. You can change this and other Account Permissions at any time.
\end{abstract}

\section{Cancel}

Puc. 12. Процес авторизації користувача у веб-додатку з використанням облікового запису Google та механізму аутентифікації Oauth2.
2. Варто розробляти лише крос-платформові додатки, щоб не бути залежним від фінансових питань ліцензування OC Windows. Найбільші перспективи в цьому напрямку мають веб-додатки. Рекомендується використовувати мови програмування РНP чи Java. Для зберігання інформації можна використати реляційні СУРБД MySQL чи Firebird. Середовищем виконання додатків при цьому будуть веб-сервери Apache чи Tomcat на платформі Linux.

3. Слід обов'язково використовувати відомі фреймворки для прискорення процесу розробки додатків, виключення великої кількості структурних помилок, надання додаткам багатшого функціоналу та зручнішого інтерфейсу. Для обох вказаних мов, РНР і Java, є велика кількість безкоштовних фреймворків.

4. Обов'язковим є використання системи контролю версій, наприклад Git. Переваги застосування си- стеми контролю версій було вказано вище. Також рекомендовано публікувати розробки на сервері Github, що значно полегшує взаємодію віддалених розробників між собою і слугує додатковою високонадійною резервною копією унікальної інформації - програмного коду.

5. Обов'язковим є також документування проекту. Сюди входить написання файлів допомоги чи інструкцій $з$ користування. Ще важливішим є документування процесу розробки, модулів та блоків коду. Частково це вирішується застосуванням системи контролю версій. Але концептуально дизайн ПЗ такі системи як Git не описують - це завдання для розробника.

Вказані кроки полегшують супроводження програмної інфраструктури власного виробництва у медичному (фармацевтичному) ВНЗ закладу протягом тривалого часу з мінімальною залежністю від плинності кадрів. 


\section{Література}

1. Семенець А. В. Організаційно - методичні підходи впровадження EMR-систем в охороні здоров'я України / A. В. Семенець // Медична інформатика та інженерія. 2013. - № 3. - С. 35-43.

2. Качмар В. О. Медичні інформаційні системи - стан розвитку в Україні / В. О. Качмар // Український журнал телемедицини та медичної телематики. - 2010. - Т. 8, № 1. C. 67-73.

3. Авраменко В. I. Формування основних напрямків розвитку інформаційних технологій в охороні здоров'я України на основі світових тенденцій / В. І. Авраменко, В. О. Качмар // Український журнал телемедицини та медичної телематики. - 2011. - Т. 9, № 2. - С. 5-15.

4. Семенець А. В. Впровадження інформаційно-комунікаційних технологій - необхідна умова ефективної розробки та супроводження сучасних програмних продуктів / А. В. Семенець // Кредитно-модульна система організації навчального процесу у вищих медичних (фармацевтичних) навчальних закладах України на новому етапі: матеріали Х ювілейної Всеукр. навч.-наук. конф. 3 міжнар. участю (Тернопіль, 18-19 квіт. 2013 р.): у 2 ч. / Терноп. держ. мед. ун-т ім. І. Я. Горбачевського. - Тернопіль : ТДМУ, 2013. - Ч. 1. - С. 455 - 463.

5. Фетісов В. С. Комп'ютерні технології в тестуванні / В. С. Фетісов [Електронний ресурс] /2011. - Режим доступу до документу :http://moodle.ndu.edu.ua/file.php/1/ Fetisov_komp_tehnol_v-testuvanni.pdf

6. Дистанційна Освіта в Україні / [Електронний ресурс] Режим доступу до документу : http://lib.if.ua/publish2008/ 1217424966.html

7. Семенець А. В. Про досвід впровадження системи електронного документообігу у медичному ВН3 / А. В. Семенець, В. Ю. Ковалок// Медична інформатика та інженерія. - 2014. - № 3. - С. 73-79.

8. Поліновський В. В. Впровадження системи електронного документообігу в науковій організації / В. В. Поліновський, М. І.Огурцов // Вісник Хмельницького національного університету. - 2010. - № 4. - С. 117-123.

9. Moodle.org: Registered sites / [Електронний ресурс] Режим доступу до документу :https://moodle.org/sites/ index.php?country=UA

10. Семенець А. В. Адаптація вільно-розповсюджуваного П3 з відкритим кодом для підтримки навчального процесу в окремому медичному ВНЗ / А. В. Семенець // Медична інформатика та інженерія. - 2013. - № 4. - С. 57-66.

11. Марценюк В. П. Модуль реєстрації виконання студентами матрикулів практичних навичок та оцінок за ОСКІ в системі електронного контролю знань на базі СДО Moodle / В. П. Марценюк, А. В. Семенець // Запорожский медицинский журнал. - 2013. - № 1. - С. 123.

12. Семенець А. В. Модуль формування розкладу відробок практичних занять та самозапису студентів в системі електронного контролю знань на базі СДО Moodle / А. В. Семенець, В. П. Марценюк // Матеріали Всеукраїнської нау- ково-методичної відеоконференції 3 міжнародною участю "Актуальні питання дистанційної освіти та телемедицини - 2013" (Запоріжжя, Київ, Лондон 10-11 жовтня 2013 р.) // Запорожский медицинский журнал. - 2013. - № 6. C. $119-120$.

13. Семенець А. В. Проблема підтримки версій системи дистанційної освіти Moodle в медичному ВН3 / А. В. Семенець // Інформаційні технології і засоби навчання. - 2014. - № 1 (39). - С. 170-181.

14. Ковальчук Л. Я. Впровадження в навчальний процес комп'ютерних технологій / Л. Я. Ковальчук, В. П. Марценюк // Медична інформатика та інженерія. - 2008. - № 1. C. 14-16.

15. Марценюк В. П. Розробка і впровадження системи електронного навчання в Тернопільському державному медичному університеті імені І.Я. Горбачевського / В. П. Марценюк// Медична освіта. - 2008. - № 2. - С. 74-75.

16. Марценюк В. П. Програмне середовище фармакокінетичних системних досліджень / В. П. Марценюк, І. С. Андрущак// Штучний інтелект. - 2009. - № 3. - С. 126-131.

17. Марценюк В. П. Інформаційна система рейтингового оцінювання діяльності викладачів ВМ(Ф)НЗ України / В. П. Марценюк, О. О. Стаханська // Медична інформатика та інженерія. - 2009. - № 3. - С. 13-21.

18. Семенець А. В. Методи та програмні засоби оцінки знань в медичній освіті: дис. ... кандидата техн. наук: 01.05.03 / Семенець Андрій Володимирович. - Тернопіль., 2011. - 163 с.

19. Ковальчук О. Л. Інформаційна система лабораторної діагностики на основі поляризаційної флуоресценції жовчі / О. Л. Ковальчук, В. П. Марценюк // Медична інформатика та інженерія. - 2010. - № 3. - С. 27-31.

20. Розробка і впровадження інформаційної системи запису (самозапису) пацієнтів на консультацію до фахівців університетської лікарні / В. П. Марценюк, П. Р. Сельський, А. В. Семенець, С. Б. Чеканов // Український журнал телемедицини та медичної телематики. - 2013. - Т. 11, № 2 . C. $173-178$.

21. Борис Р. М. Інформаційна система лабораторної діагностики політравм / Р. М. Борис, В. П. Марценюк// Вісник соціальної гігієни та організації охорони здоров'я України. - 2013. - № 2 (65). - С. 44-48.

22. Марценюк В. П. Програмне середовище епідеміологічних системних досліджень / В. П. Марценюк, О. М. Кучвара // Наукові праці Чорноморського державного університету імені Петра Могили. - 2014. - № 237. - Вип. 225. C. 11-18.

23. Hussain Cassim Using Frameworks to Build Websites and Web Applications / [Електронний ресурс] Режим доступу до документу : https://www.ostraining.com/blog/webdesign/frameworks/ 24. Lammert Westerhoff State of Web Development 2014 / [Електронний ресурс] - Режим доступу до документу : http://blog.xebia.com/2014/06/06/state-of-web-development2014/ 
25. Comparison of web application frameworks Wikipedia, the free encyclopedia/ [Електронний ресурс] Режим доступу до документу : h t t p : / / e n.w i k i p e d i a . or g/w i k i / Comparison_of_web_application_frameworks

26. JavaFX - The Rich Client Platform / [Електронний ресурс] - Режим доступу до документу : http://www.oracle.com/ technetwork/java/javase/overview/javafx-overview2158620.html
27. Семенець А. В. Концепція побудови інформаційної інфраструктури медичного ВНЗ з використанням вільнорозповсюджуваного програмного забезпечення з відкритим кодом / А. В.Семенець, В. Ю. Ковалок // Інформаційні технології і засоби навчання. - 2014. - № 3. - С. 277-288. 28. Семенець А. В. Застосування хмарних технологій при побудові інформаційної інфраструктури медичного ВНЗ / А. В. Семенець // Медична освіта. - 2014. - №> 1. - С. 99-104. 